\title{
Immunohistochemical study of tissue factor expression in normal intestine and idiopathic inflammatory bowel disease
}

\author{
L More, R Sim, M Hudson, A P Dhillon, R Pounder, A J Wakefield
}

\begin{abstract}
Aims-To investigate the localisation of tissue factor expression in normal and inflamed intestine.

Methods-Serial cryostat sections of tissue taken from patients with Crohn's disease $(n=8)$, ulcerative colitis $(n=5)$, and from controls $(n=5)$ were stained with haematoxylin and eosin and immunostained for tissue factor, collagen type IV, fibrinogen and platelet glycoprotein IIIa.

Results-In control tissues tissue factor was present as a continuous layer along the epithelial basal lamina: sections from controls did not immunostain for fibrinogen or platelets. In non-ulcerated inflamed mucosa, tissue factor staining intensified in cases of Crohn's disease and was associated with fibrin deposition. Staining for tissue factor was either patchy or absent in cases of ulcerative colitis and there was no fibrin deposition. This change accompanied the early destruction of the epithelial basal lamina in ulcerative colitis that was not seen in Crohn's disease. In both diseases tissue factor expression in severely inflamed and ulcerated mucosa was present on lamina propria macropages and vascular endothelium and was associated with fibrin or platelet thrombi. In three of eight cases of Crohn's disease tissue factor expression and thrombi were evident in areas of submucosal vasculitis. These were not seen in adjacent normal vessels. Conclusions-These observations are consistent with a tissue factor haemostatic barrier in the intestine: this barrier seems to be incomplete or defective in ulcerative colitis. Tissue factor expression by macrophages and endothelial cells may be important, particularly in the microvascular thrombosis and induration which are characteristic of Crohn's disease.
\end{abstract}

$(\Im$ Clin Pathol 1993;46:703-708)

Tissue factor is a membrane bound glycoprotein responsible for activating the extrinsic pathway of blood coagulation. ${ }^{1}$ Tissue factor is essentially expressed by a number of extravascular cells, including smooth muscle cells and fibroblasts and, as such, is responsible for initiating haemostasis when blood comes into contact with damaged tissues. ${ }^{2}$
When exposed to plasma, tissue factor binds and activates factor VII, leading to thrombin generation and fibrin deposition. ${ }^{1}$ Thrombin stimulates platelet activation ${ }^{2}$ and thus augments the haemostatic process. Kinetic analysis of tissue factor initiated coagulation in vitro suggests that this pathway is primarily responsible for maintaining haemostasis in vitro. $^{1}$

Drake et al have recently described the distribution of tissue factor expression in the normal gastrointestinal tract. ${ }^{2}$ They noted that throughout the bowel there is a continuous layer of tissue factor expressed by pericryptal fibroblasts, located immediately below the epithelial basement membrane. They suggested that this distribution was consistent with the role of a haemostatic barrier.

Tissue factor procoagulant activity is not normally expressed by macrophages or by cells within the intravascular compartment: in certain pathological conditions tissue macrophages and vascular cells including endothelium and circulating monocytes can be induced to express tissue factor, ${ }^{34}$ leading to the deposition of fibrin within tissues and thrombosis in blood vessels. Activation of this pathway leads to induration and ischaemia of the dependent tissues. ${ }^{56}$ Several biological stimuli can induce the expression of procoagulant activity on cells of monocyte lineage and endothelium-including interleukin-1 (IL1), ${ }^{378}$ tumour necrosis factor (TNF), ${ }^{9}$ and bacterial lipopolysaccarride (LPS).$^{10}$

We and others have already provided evidence for the participation of this pathway in the pathogenesis of idiopathic inflammatory bowel disease. ${ }^{1-14}$ In Crohn's disease we suggested that the multifocal induction of endothelial cell procoagulant activity might be one of the initiating events in the evolution of this condition. ${ }^{12}$ Several reports have also suggested that mucosal microvascular changes, including endothelial cell activation $^{15}$ and the formation of microthrombi, ${ }^{16}{ }^{17}$ are antecedents of epithelial ulceration in ulcerative colitis. Furthermore, intestinal bleeding is a common feature of inflammatory bowel disease, particularly in patients with ulcerative colitis. ${ }^{18}$

\section{Methods}

Eight patients with Crohn's disease, five patients with ulcerative colitis, and five controls with non-inflammatory conditions were studied (table 1). Crohn's disease and ulcera- 
Table 1 Clinical data and treatment regimen's in 21 patients studied

\begin{tabular}{|c|c|c|c|c|c|}
\hline Case No & Diagnosis & Age & Sex & Site of tissue & Treatment \\
\hline $\begin{array}{l}1 \\
2 \\
3 \\
4 \\
5 \\
6 \\
7 \\
8\end{array}$ & Crohn's disease & $\begin{array}{l}24 \\
66 \\
38 \\
55 \\
33 \\
29 \\
41 \\
25\end{array}$ & $\begin{array}{l}\mathrm{F} \\
\mathrm{M} \\
\mathrm{F} \\
\mathrm{F} \\
\mathrm{F} \\
\mathrm{M} \\
\mathrm{F} \\
\mathrm{M}\end{array}$ & $\begin{array}{l}\text { Ileo-caecum } \\
\text { Ileum } \\
\text { Ileum } \\
\text { Ileo-caecum } \\
\text { Neo-terminal ileum } \\
\text { Ileo-caecum } \\
\text { Ileo-caecum } \\
\text { Ileo-caecum }\end{array}$ & $\begin{array}{l}\text { SSZ } \\
\text { P } \\
\text { SSZ } \\
\text { Nil } \\
\text { SSZ } \\
\text { SSZ }\end{array}$ \\
\hline $\begin{array}{r}9 \\
10 \\
11 \\
12 \\
13\end{array}$ & Ulcerative colitis & $\begin{array}{l}27 \\
60 \\
33 \\
30 \\
28\end{array}$ & $\begin{array}{l}\mathrm{M} \\
\mathrm{F} \\
\mathrm{M} \\
\mathrm{M}\end{array}$ & $\begin{array}{l}\text { Colon } \\
\text { Colon } \\
\text { Rectum } \\
\text { Colon } \\
\text { Colon }\end{array}$ & $\begin{array}{l}\mathbf{P} \\
\mathbf{P} \\
\mathbf{P} \\
\mathbf{P} \\
\mathbf{P}\end{array}$ \\
\hline $\begin{array}{l}14 \\
15 \\
16 \\
17 \\
18\end{array}$ & $\begin{array}{l}\text { Carcinoma of rectum } \\
\text { Carcinoma of caecum } \\
\text { Carcinoma of rectum } \\
\text { Descending perineum } \\
\text { Small bowel lymphoma }\end{array}$ & $\begin{array}{l}71 \\
75 \\
81 \\
56 \\
50\end{array}$ & $\begin{array}{l}\mathrm{M} \\
\mathrm{F} \\
\mathbf{M} \\
\mathrm{M} \\
\mathbf{M}\end{array}$ & $\begin{array}{l}\text { Colon } \\
\text { Ileum } \\
\text { Colon } \\
\text { Rectum } \\
\text { Ileum }\end{array}$ & \\
\hline
\end{tabular}

SSZ = Sulphasalazine; $\mathbf{P}=$ Prednisolone; $\mathrm{AZA}=$ Azathioprine.

tive colitis were diagnosed using conventional endoscopic, radiological, and histological criteria. All specimens were obtained at surgical resection. The controls with non-inflammatory bowel disease comprised three patients undergoing right hemicolectomy for carcinoma of the caecum, and two patients undergoing anterior resection, one for carcinoma of the rectum and one for descending perineum syndrome. In specimens of malignant disease blocks were taken from macroscopically normal bowel that was at least $5 \mathrm{~cm}$ from the tumour margin.

Immediately after resection the main arterial pedicle supplying the specimen was cannulated and flushed with anticoagulated $0.9 \%$ saline until the venous effluent was clear.

Blocks of tissue (about $1 \mathrm{~cm}^{3}$ ) were taken from the resected specimens, embedded in OCT compound on cork blocks, immersed in Isopentane and snap frozen in liquid nitrogen. The time from resection to freezing was about 10 minutes. From these blocks, $5 \mu \mathrm{m}$ cryostat sections were cut and placed on polyL-lysine coated slides, which were then dried at room temperature for 10-15 minutes. Forty serial sections were cut from each block and every tenth level was stained with haematoxylin and eosin. Blocks were selected based on these stained sections to include areas both with and without mucosal ulceration. To make valid qualitative comparisons between the immunostaining characteristics of Crohn's disease, ulcerative colitis, and non-inflammatory controls, sections from each of these diseases were processed and immunostained in batches, and comparisons were made between sections within the same batch. This was an attempt to reduce the

Table 2 Tissue processing

\begin{tabular}{llllll}
\hline $\begin{array}{l}\text { Target } \\
\text { antigen }\end{array}$ & $\begin{array}{l}\text { Antibody } \\
\text { type }\end{array}$ & Dilution & $\begin{array}{l}\text { Incubation } \\
\text { time }\end{array}$ & $\begin{array}{l}\text { Incubation } \\
\text { temperature }\end{array}$ & $\begin{array}{l}\text { Immunoperoxidase } \\
\text { method }\end{array}$ \\
\hline $\begin{array}{l}\text { Tissue } \\
\text { factor }\end{array}$ & $\begin{array}{l}\text { Mouse } \\
\text { monoclonal }\end{array}$ & 1 in 20 & Overnight & $4^{\circ} \mathrm{C}$ & Avidin biotin \\
$\begin{array}{l}\text { Fibrinogen } \\
\text { Rabbit } \\
\text { polyclonal }\end{array}$ & 1 in 1000 & 30 minutes & Room & $\begin{array}{l}\text { Peroxidase } \\
\text { anti-peroxidase }\end{array}$ \\
$\begin{array}{c}\text { Collagen } \\
\text { type IV }\end{array}$ & $\begin{array}{c}\text { Mouse } \\
\text { monoclonal }\end{array}$ & 1 in 50 & 60 minutes & Room & Avidin biotin \\
$\begin{array}{c}\text { Platelet } \\
\text { glycoprotein } \\
\text { IIIa }\end{array}$ & $\begin{array}{c}\text { Mouse } \\
\text { monoclonal }\end{array}$ & 1 in 40 & Overnight & $4^{\circ} \mathrm{C}$ & Avidin biotin \\
\hline
\end{tabular}

minor variations that can occur during immunostaining as a result of using reagents from different batches.

\section{IMMUNOSTAINING}

Tissue factor monoclonal antibodies were a gift from Dr T S Edgington (Scripps Clinic, La Jolla, California, USA). A pool of four monoclonal antibodies reactive with human tissue factor were used, the isolation and characterisation of which have been reported elsewhere. ${ }^{18}$ Of the four antibodies used, two recognise functional epitopes on tissue factor and two recognise non-functional epitopes, so that tissue factor would still be recognised in tissues that may have bound factor VII in vivo. ${ }^{20}$ These antibodies were reported to bind strongly to cultured human cell lines expressing tissue factor, but not to cell lines in which this activity is absent. ${ }^{2}$ Antibodies were obtained from hybridoma culture supernatant fluids, and were used at a working concentration of $0.1 \mu \mathrm{g} / \mathrm{ml}$ in reagent diluent (20\% bovine serum albumin, $0.05 \%$ thimersal in $0.05 \mathrm{M}$ TRIS-HCl, $0.9 \% \mathrm{NaCl}, \mathrm{pH}$ $7 \cdot 4$ ).

Collagen type IV (Dako, High Wycombe, Bucks) was used to identify vascular and epithelial basal laminae. Fibrinogen (Dako) and platelet glycoprotein IIIa (Dako) were used to help identify foci of fibrin deposition and microthrombi.

\section{TISSUE PROCESSING}

Sets of eight serial sections (four test, four control) were fixed for 10 minutes in Zamboni's fixative for tissue factor and $4 \%$ neutral buffered formalin for all other antigens. Extensive screening before this study had identified Zamboni's as the most suitable fixative for the identification of tissue factor (L More, unpublished data).

Slides were washed in methanol for one minute and treated with hydrogen peroxide to block endogenous peroxidase activity. Sections were washed twice in TRIS-buffered saline for 15 minutes before $5 \%$ normal swine serum was applied to block non-specific antibody binding. Sections were drained and primary antisera were applied (table 2). After incubation, sections were washed in TRISbuffered saline for 10 minutes and incubated with secondary biotinylated antibody for the avidin biotin complex method or a bridge antibody for the peroxidase anti-peroxidase method. Horseradish peroxide was used as the label, and hydrogen peroxide and diaminobenzidine were used as the colorisation step. Sections were counterstained in Mayer's haematoxylin. Negative control sections were treated identically, except that the primary antibody was omitted.

\section{Results}

NORMAL INTESTINAL TISSUE

The immunostaining patterns for collagen type IV and tissue factor were similar in both normal small and large intestine. No immunostaining was seen in the negative controls. 
Figure $1 A$ Normal small intestine: epithelial basal lamina (large arrow) and vascular basal lamina (small arrow)

demonstrated by collagen type IV immunostaining.

Figure 1B Normal small intestine: tissue factor expression at the level of the epithelial basal lamina. Prominent nuclear staining (arrowed) suggests a possible cellular origin for tissue factor (tissue factor immunostaining).
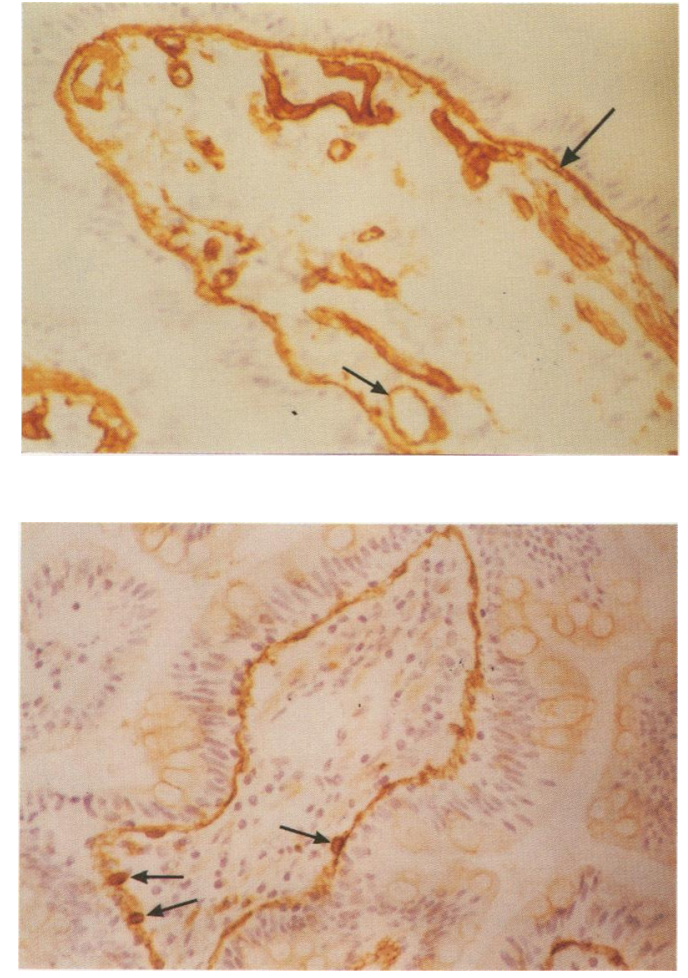

\section{Collagen type IV}

Both vascular and epithelial basal laminae stained strongly for collagen type IV. In both of these structures basal lamina was represented by a continuous layer that stained with consistent intensity (fig 1A).

\section{Tissue factor}

In sections of normal intestine tissue factor immunostaining was found in a continuous layer along the epithelial basal lamina, with only the occasional positive fibroblast-like cell in the lamina propria, and with no other staining in the lamina propria (fig 1B).

\section{Fibrinogen and platelet glycoprotein III a}

Normal vessels did not stain positively for either fibrinogen or platelet glycoprotein IIIa, results which are consistent with the procedure of heparin-saline vascular perfusion immediately after intestinal resection.

\section{CROHN'S DISEASE}

As with normal intestine, there were no differences in the staining patterns between tissue from colon and small intestine for the

Figure 2 Crohn's disease. Submucosal granulomatous vasculitis showing foci of vascular mural injury (arrowed) (collagen type IV immunostaining). Tissue factor could not be shown on serial sections from this tissue block.

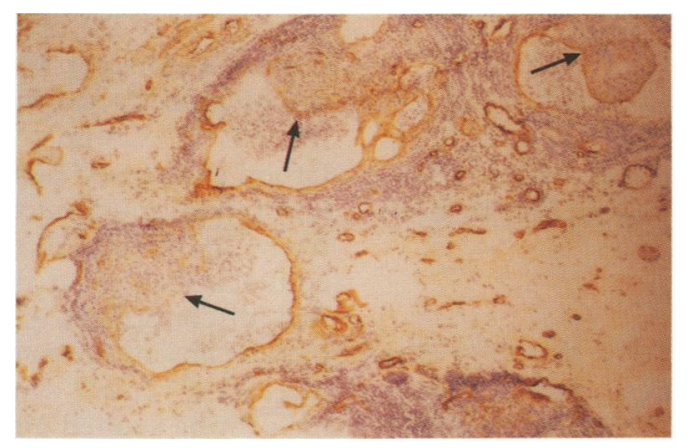

four immunostaining reagents used.

\section{Collagen type IV}

In histologically non-inflamed sections of Crohn's disease and in those sections that exhibited cellular infiltration of the lamina propria or submucosa before ulceration, the epithelial basal lamina was preserved, both in terms of its continuity and consistency of staining. In these respects it was indistinguishable from normal intestine.

In sections of Crohn's disease the vascular basal lamina of mucosal vessels appeared normal, suggesting that the vessels were inact. In the submucosa, however, focal (often granulomatous) vascular inflammation was seen in haematoxylin and eosin stained sections, and confirmed by the presence of cellular infiltration and disintegration or reduplication of the vascular basal lamina, in serial sections stained with collagen type IV (fig 2). These inflamed vessels were often located below intact mucosa and immediately adjacent to structurally normal vessels, emphasising the focal nature of this process.

\section{Tissue factor}

Mucosal tissue factor In areas of histologically normal mucosa in Crohn's disease tissue factor appeared as the continuous layer previously observed in normal intestine. In areas of cellular infiltration of the lamina propria tissue factor immunostaining increased in intensity, particularly at the apices of small intestinal villi and colonic crypts (fig 3A). Staining also appeared in association with pericryptal fibroblasts and lamina propria macrophage-like cells (fig 3A).

In regions of superficial ulceration tissue factor continued to be expressed as a continuous layer, but in deeper ulcers this layer was disrupted and the endothelium of small vessels underlying these areas of ulceration seemed to stain positively for tissue factor (fig 3B). The vascular origin of this immunostaining was confirmed on serial sections that were stained for collagen type IV (fig 3C). In these deeper ulcers mucosal tissue factor immunostaining disappeared simultaneously with destruction of the epithelial basal lamina (fig 3C).

Submucosal vasculitis This was seen in seven of eight cases, yet tissue factor immunostaining was evident in only a few of these inflamed vessels involved in vasculitis (seen in three of eight cases). In these inflamed vessels tissue factor staining was often intense and seemed to involve the entire vessel, making it difficult to distinguish the cellular origin of this activity.

Fibrinogen and platelet glycoprotein III a

In the absence of ulceration, and in some cases, without cellular inflammation, discrete fibrin or platelet thrombi were observed in some mucosal vessels. With progressive epithelial inflammation and ulceration, fibrinogen staining appeared at the level of the epithelial basal lamina, suggesting that it was being deposited at the tissue factor interface 


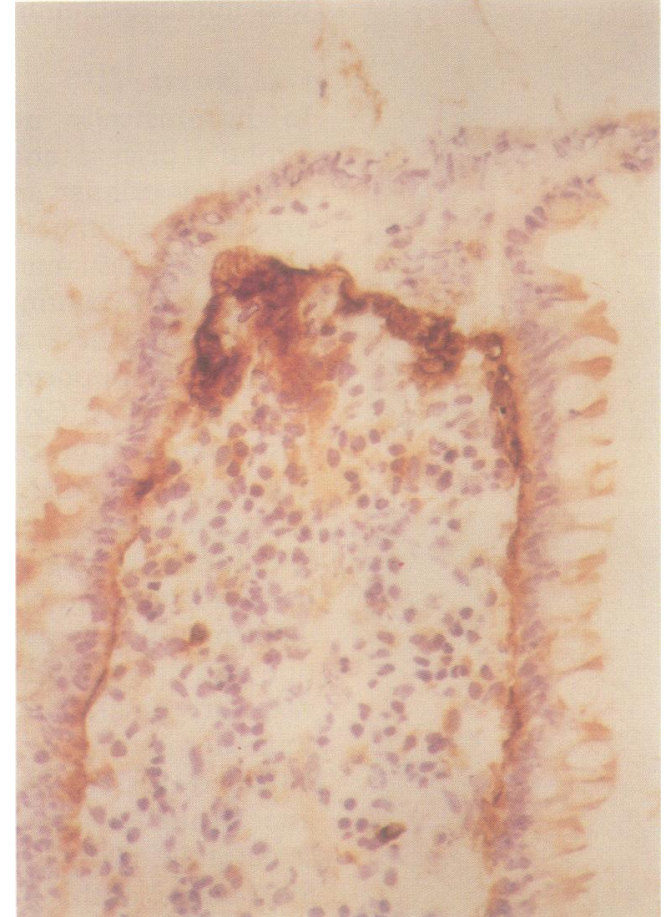

Figure $3 A$ Ileal Crohn's disease. Intense tissue factor expression at the villous tip in association with inflammation of the lamina propria (tissue factor immunostaining).

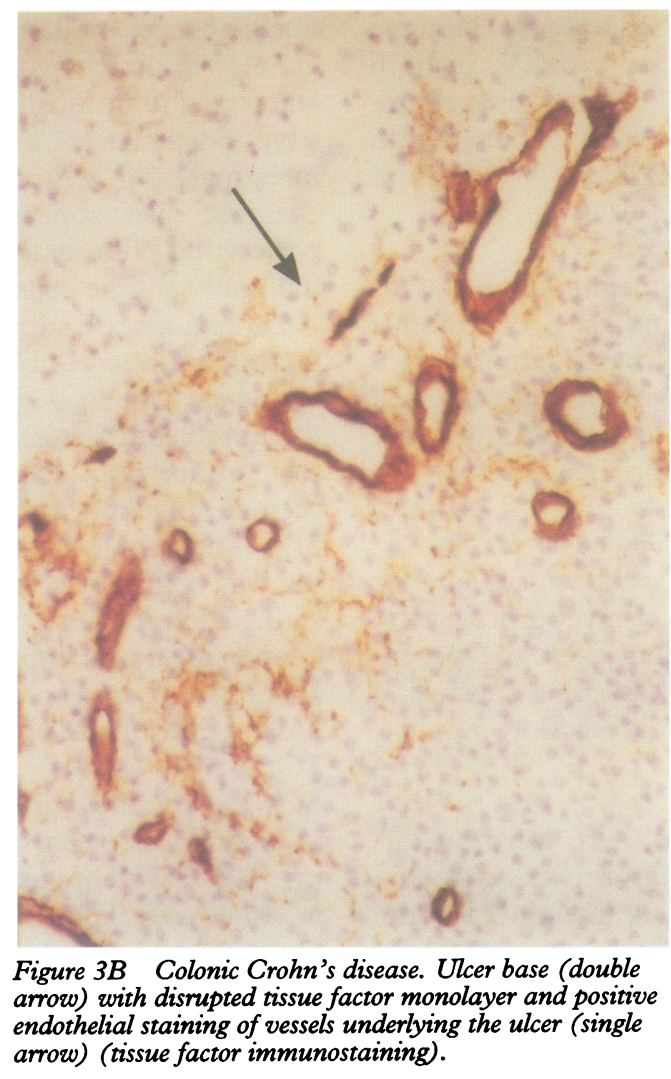

in the epithelium (fig 4). In the submucosa deposition of both fibrin and platelets was evident in foci of vasculitis, but not in noninflamed vessels.

\section{ULCERATIVE COLITIS}

Collagen type IV

In histologically normal areas of colon tissue from patients with ulcerative colitis epithelial

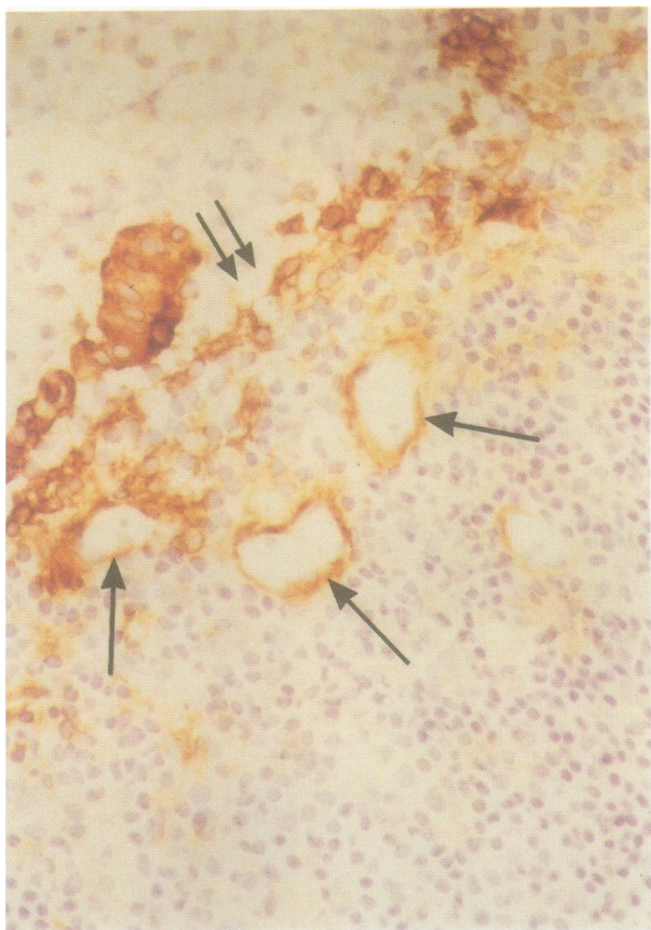

Figure 3C Serial section. Vessels underlying the ulcer base (arrowed) confirmed by collagen type IV immunostaining. Epithelial basal lamina has been destroyed.

basal lamina appeared the same as in both intestinal tissue from normal controls and unaffected areas of Crohn's disease. In contrast, however, the appearance of the epithelial basal lamina in ulcerative colitis was changed in the presence of inflammation before epithelial loss. These changes were characterised by discontinuity of the basal lamina and reduction in the intensity and consistency of immunostaining, leading to a complete absence of immunostaining in areas of early ulceration (fig 5A). These changes were focal and started as apparently small lesions which progressively affected larger areas of the basal lamina. The quality of immunostaining of the basal lamina could be judged against that of the adjacent vascular basal lamina of mucosal vessels: in histologically normal colon tissue these two structures stained with roughly equal intensity (fig $1 \mathrm{~A}$ ).

\section{Tissue factor}

In areas of histologically normal colon, tissue factor immunostaining was similar to that of control colon and unaffected areas of Crohn's disease. The changes in tissue factor which accompanied mucosal inflammation in ulcerative colitis paralleled those in collagen type IV staining of the epithelial basal lamina, and contrasted sharply with the increase in intensity of tissue factor that accompanied inflammation in Crohn's disease. While, as in Crohn's disease, pericryptal fibroblasts and infiltrating mononuclear cells stained positively for tissue factor, staining along the epithelial basement membrane became weak and discontinuous (fig 5B), and was completely absent in some places. In areas of ulceration vessels within the underlying lamina propria stained positively for tissue factor. 
Figure 4 Colonic Crohn's disease. Fibrin deposition at the level of the epithelial basal lamina and inflamed mucosa (fibrinogen immunostaining).
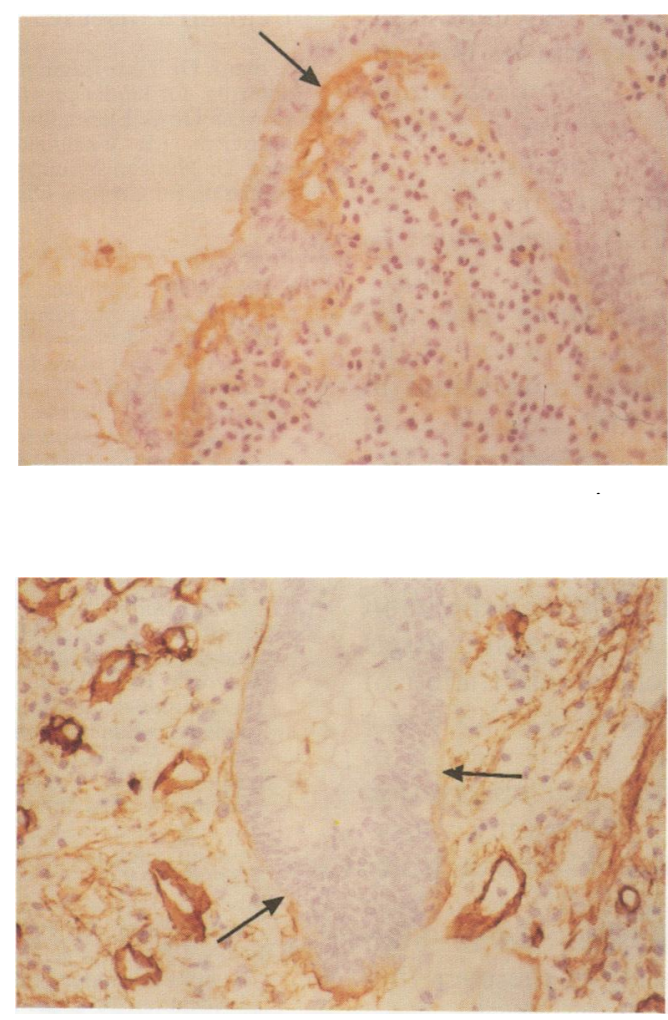

Figure 5A Ulcerative colitis. Deterioration of collagen type IV immunostaining in the epithelial basal lamina (arrowed) associated with mucosal inflammation. Vascular basal lamina is well preserved.
Figure 5B Ulcerative colitis. Deterioration of tissue factor immunostaining in the epithelial basal lamina (large arrow) in inflamed mucosa. Macrophage-like cells stain positively for tissue factor (small arrow).

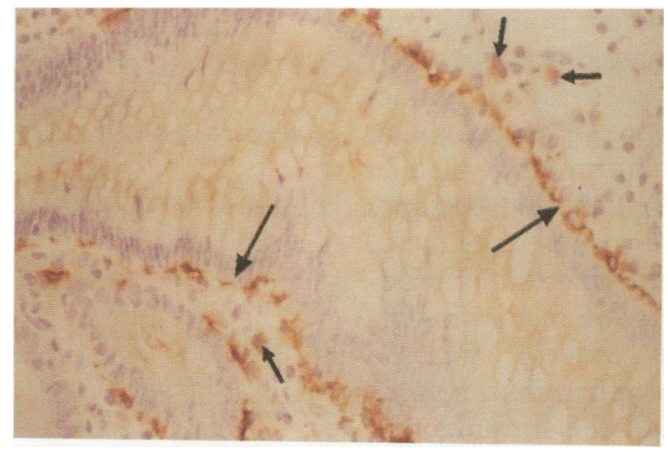

Fibrinogen and platelet glycoprotein IIIa

In contrast to Crohn's disease, fibrin deposition at the level of the epithelial basal lamina in areas of mucosal inflammation and ulceration was erratic or absent in ulcerative colitis. This was seen in parallel with the deterioration in immunostaining of both collagen type IV and tissue factor. Fibrin microthrombi, such as those seen in Crohn's disease, were not seen in the sections of ulcerative colitis studied. Platelet glycoprotein IIIa positive thrombi, however, were seen in the presence of inflammation, in vessels underlying both ulcerated and non-ulcerated mucosa. Vessels deep to the lamina propria showed no evidence of either inflammation, tissue factor expression, or microthrombi.

\section{Discussion}

This study describes some novel observations of the patterns of intestinal tissue factor expression in both normal and pathological states. Drake et al provided the original description of the localisation of tissue factor in the normal gastrointestinal tract ${ }^{2}$ : in their specimens they noted that there was an intense localisation of tissue factor in the one to two cell thick layer of pericryptal fibroblasts, located immediately below the epithelial basement membrane. We found that in normal intestine, tissue factor is essentially expressed in a continuous layer along the epithelial basement membrane, with only the occasional fibroblast exhibiting positive staining within the lamina propria. We observed that it is during the early stages of inflammation that subepithelial macrophages and fibroblasts become positive for tissue factor.

This apparent disparity in results may be explained by the relative intervals between resection and snap-freezing of tissues in the two studies. In the former study, tissues were obtained from surgical and necropsy specimens, and frozen within six hours of removal, ${ }^{2}$ in the present study tissues were snap frozen immediately after surgical resection and heparin-saline perfusion. During prolonged post-surgical episodes of mucosal ischaemia pericryptal fibroblasts could have been induced to express tissue factor.

There were notable differences in the immunostaining patterns for both tissue factor and collagen type IV between specimens from Crohn's disease and ulcerative colitis. These differences were evident in the epithelial basal lamina during inflammation, but before mucosal ulceration. In the inflamed mucosa of Crohn's disease, collagen type IV staining is preserved and tissue factor staining intensifies. In contrast, in ulcerative colitis, epithelial basal lamina seems to be an early focus of tissue damage, and loss of collagen type IV staining is accompanied by loss of staining for tissue factor. Donellan's detailed study of the early ultrastructural changes in ulcerative colitis ${ }^{16}$ describes the earliest demonstrable abnormality as focal degeneration of the "reticulin" component of the epithelial basal lamina, and this is supported by the observations of others ${ }^{21}$ : Donellan noted that foci of degenerating basal lamina gradually extend to involve more and more of this layer, and our observations lend support to these findings.

In parallel with the degeneration of the epithelial basal lamina in ulcerative colitis, tissue factor immunostaining deteriorates with progressive inflammation. Loss of the integrity of the tissue factor haemostatic barrier in ulcerative colitis may be an important contribution to the chronic blood loss that is a feature of this disease. ${ }^{18}$

The problems associated with quantifying the changes of tissue factor expression in immunohistochemically processed specimens are acknowledged. We are presently conducting hybridisation studies that may allow us to identify the cellular source of tissue factor in the gut. This technique might also allow the quantification of intestinal tissue factor expression in normal and pathological states.

As far as we are aware this is the first report of the immunohistochemical localisation of pathological tissue factor expression in 
macrophages and vascular endothelium. This cellular procoagulant activity can be induced by cytokines including IL-1, ${ }^{37-9}$ concentrations of which are raised in the intestine in inflammatory bowel disease. ${ }^{22} 23$ Matsumoto et al recently provided immunohistochemical evidence of endothelial IL-1 expression in mucosal vessels in ulcerative colitis. ${ }^{15}$ Endothelial cell IL-1 expression by these vessels might contribute to the induction of tissue factor which has been demonstrated in this study. In ulcerative colitis vessels deep to the lamina propria did not express tissue factor and this agrees with the characteristic localisation of inflammation to the mucosa in this condition.

In Crohn's disease tissue factor expression was evident in some submucosal vessels which were the site of cellular infiltration of the vessel wall-that is, vasculitis. This was a focal event with adjacent vessels devoid of any tissue factor activity, an observation which suggests that the inflammatory stimulus for vascular inflammation derives from, and is localised to, the affected vessel. These submucosal changes are seen before both inflammation and ulceration of the overlying mucosa.

The functional activity of the tissue factor in these inflamed vessels is suggested by the presence of both fibrin and platelets, features which were not seen elsewhere in the submucosa in serial tissue sections. Some obviously inflamed vessels did not stain for tissue factor, despite indirect evidence of procoagulant activity in the form of fibrin and platelet deposition. It is possible either that epitopes recognised by the cocktail of anti-tissue factor monoclonal antibodies were masked by products of coagulation, that tissue factor (having initiated the coagulation process) was no longer expressed in these inflammatory foci, or that tissue factor was not the stimulus that initiated coagulation.

We recently obtained serological evidence for persistent fibrin formation in both clinically active and inactive phases of Crohn's disease, ${ }^{24}$ data which corroborate the present immunohistochemical findings. Mesentric vasculitis is probably responsible, at least in part, for these systemic changes.

Based on our observations we suggest that damage to the functional integrity of the tissue factor layer in the lamina propria may predispose to gastrointestinal bleeding, a feature particularly of ulcerative colitis ${ }^{18}$ (and which may be relevant to other pathological and iatrogenic conditions). The pathological induction of monocyte or macrophage and vascular endothelial cell tissue factor expression reported in this study is likely to initiate the fibrin deposition and microvascular thrombosis which are part of the pathogenesis of Crohn's disease.

We thank Dr Tom Edgington of The Scripps Clinic, La Jolla, California, for kindly providing the anti-tissue factor reagents and Miss Doris Elliott for her help in the preparation of the manuscript. Mr Wakefield is supported by the Wellcome Trust. Dr Hudson is supported by a grant from the National Association for Crohn's Disease and Colitis.

1 Bronza JP. Cellular regulation of tissue factor. Blood Coagulation and Fibrinolysis 1990;1:415-26.

2 Drake TA, Morrissey JH, Edgington TS. Selective cellular expression of tissue factor in human tissues. Am F Pathol 1989;134:1087-97.

3 Edwards RL, Rickles FR. Macrophage procoagulants. Progress in haemostasis and thrombosis. New York: Grune and Stratton, 1984;183-209.

4 Narworth PP, Handley D, Stern DM. The multiple levels of endothelial cell-coagulation factor interaction. Clin Haematol 1986;15:293-321.

5 Edwards RL, Rickles FR. Delayed hypersensitivity in man: effects of systemic anticoagulation. $\mathcal{f}$ Immunol $1980 ; 125: 606-11$

6 Colvin RB, Dvorack HF. Role of clotting system in cell mediated immunity. F Immunol 1975;114:377-87.

7 Narworth PP, Handley DA, Esmon CT, Stern DM. Interleukin-1 induces endothelial cell procoagulant activity while suppressing cell surface anticoagulant activity. Proc Natl Acad Sci USA 1986;83:3460-4.

8 Bevilaqua MP, Pober JS, Majeau GR, Cotran RS, Gimbrone MA. Interleukin-1 (IL-1) induces biosynthesis and cell surface expression of procoagulant activity in human vascular endothelial cells. $f$ Exp Med 1984; 160:618-23.

9 Pober JS. Cytokine mediated activation of the vascular endothelium. Am F Pathol 1988;133:426-33.

10 Rickles PR, Levin J, Hardin JA. Tissue factor generation by human mononuclear cells: effects of endotoxin and dissociation of tissue factor generation from mitogenic response. F Lab Clin Med 1977;89:792-803.

11 Edwards RL, Levine JB, Green R, et al. Activation of blood coagulation in Crohn's disease. Gastroenterology 1987;92:329-37.

12 Wakefield AJ, Sawyerr AM, Dhillon AP, et al. Pathogenesis of Crohn's disease: multifocal gastrointestinal infarction. Lancet 1989;ii:1057-62.

13 Wakefield AJ, Sankey EA, Dhillon AP, et al. Granulomatous vasculitis in Crohn's disease. Granulomatous vasculitis in
Gastroenterology 1991;100:1279-87.

14 Pounder RE, Wakefield AJ, Sawyerr AM, Hudson M, Dhillon AP. Pathogenesis of Crohn's disease: granulomatous vasculitis and multifocal gastrointestinal infarction. In: Goebell H, Malchow H, Eve K, Koelbel CH, eds. Inflammatory bowel disease progress in basic research and clinical implications. London: Kluwer, 1991:33-8.

15 Matsumoto T, Ritano A, Nakamura S. Possible role of vascular endothelial cells in immune responses in colonic mucosa examined immunocytochemically in subjects with and without ulcerative colitis. Clin Exp Immunol 1989;78:424-30.

16 Donnellan WL. Early histological changes in ulcerative colitis. A light and electron microscopic study. Gastroenterology 1966;50:519-40.

17 Sawyerr AM, Wakefield AJ, Rowles PM, et al. Microvascular changes in Crohn's disease: examination by vascular casting and scanning electron microscopy. Gastroenterology 1990;5:A203.

18 Gloster DJ. Indications for operation in inflammatory bowel disease. In: Kisner JB, Shorter RG, eds. Inflammatory bowel disease. 3rd edn. Philadelphia, Lea and Fabiger, 1988:549-84.

19 Morrissey JM, Fair DS, Edgington TS. Monoclonal antibody analysis of purified and cell-associated tissue facbody analysis of purified and cell
tor. Thromb Res 1988;52:247-61.

20 tor. Thromb Res $1988 ; 52: 247-61$. bodies inhibit tissue factor function by two distinct bodies inhibit tissue factor function by two distinct
mechanisms: evidence for a functional region of tissue mechanisms: evidence for a functional region of tis
factor not involved in factor VII binding. (In press).

21 Levine MD, Kirsner JB, Hotz A. A new concept in the pathogenesis of ulcerative colitis. Science 1951;114: 552-3.

22 Mahida YR, Wu K, Jewell DP. Enhanced production of Interleukin-1 by mononuclear cells isolated from mucosa with active ulcerative colitis and Crohn's disease. Gut 1989;30:835-8.

23 Satsangi J, Wolestencroft JC, Ainley CC, Dumonde DC, Thompson RPH. Interleukin-1 in Crohn's disease. Clin Exp Immunol 1987;67:594-605.

24 Hudson $M$, Hutton RA, Wakefield AJ, Sawyerr AM, Pounder RE. Evidence for accelerated thrombogenesis in Crohn's disease. Blood Coagulation and Fibrinolysis 1993;3:773-8. 